\title{
DETERMINATION OF FINANCIAL FACTORS IN THE LATEST THEORIES OF ECONOMIC GROWTH OF TERRITORIAL COMMUNITIES
}

\author{
HALYNA VOZNYAK, KRYSTYNA PATYTSKA, TARAs KLOBA
}

\begin{abstract}
In today's modern circumstances ensuring the economic growth of territorial communities requires theoretical redefining and additional research, since new challenges have negatively affected the well-being of the population and ensuing progress.

The purpose of the article is to determine financial factors in the latest theories of economic growth of territorial communities.

Scientific approaches to the definition of "territorial community" are generalized, own approach is offered and the main features of territorial community (territorial, natural, socialpsychological, historical-cultural, organizational-functional, political, economic) are substantiated. Emphasis is placed on the need for a new theoretical approach to the development of territorial communities based on the synthesis and combination of basic guidelines and principles of modern scientific concepts and models, their interpretation in the context of local development. The latest theories of economic growth are studied, including: the theory of endogenous growth, inclusive development and the theory of sustainable development (E. Ostrom's concept of community resource management is highlighted). It is substantiated that the model of endogenous growth is focused on reducing inequality of economic development through the use of internal factors, mechanisms of management and management of the territory. There are two vectors of achieving inclusive development of territorial communities: internal - maximum involvement of community members in the process of its development; external - ensuring access of members of the territorial community to the opportunities provided by more developed communities. It is emphasized that the key idea in E. Ostrom's research is to achieve efficiency and substantiation of ways of community management of common resources. Within the framework of the theory of inclusive development, a review of the concept of financial inclusion, which raises the issue of community development - "banking deserts". The existence of interdependence of perception of members of territorial communities - "banking deserts" of opportunities and prospects of obtaining banking services is indicated, which requires the involvement of theoretical foundations of behavioral economics in the study of this issue. The factors of economic growth of territorial communities are systematized, which are united into five groups: natural, factors of human development; social, production and financial. The financial factors of economic growth of territorial communities include: budget; investment, inflation, monetary. The expediency of applying the ideas of the latest theories of economic growth in the process of analyzing financial factors is substantiated.
\end{abstract}

Keywords: territorial community, financial factors of economic growth, endogenous growth, inclusive development, sustainable development, common resources, financial inclusion.

JEL Classification: 011, 016. 


\section{INTRODUCTION}

The new challenges caused by the consequences of the pandemic and the socio-economic crisis had a negative impact on the welfare of the population, exacerbated a number of economic problems of further functioning and progress of Ukraine as a whole and newly formed communities, that have entered a fundamentally new phase of development (including through the reform of administrative and financial decentralization). On the other hand, in Ukraine, ensuring the financial and managerial capacity of territorial communities is significantly complicated by the deep institutional crisis and the preservation of established hierarchical relations at all levels. The sensitivity of the economy of territorial communities to these preconditions is increased by its underdevelopment and the problem of situational motivation in the behavior and actions of economic entities, which is not focused on strategic long-term community development and sustainable networking as the basis of its economic and social development.

This actualizes the issues that were mentioned above and indicates the urgent need for theoretical comprehension of the issue of economic growth of territorial communities in the new conditions.

\section{THEORETICAL BACKGROUND}

Due to its socio-economic significance, the outlined topics are in the focus of scientific research of representatives of economic and financial science. Thereby, one of the fundamental models of economic growth of the territory in modern conditions is the theory of endogenous scientific and technological progress of P. Romer, in which scientific and technological progress is "a factor of economic growth generated by internal causes" [1], and economic growth directly depends on the amount of human capital, concentrated in the field of knowledge acquisition. The factors of economic growth in this theory are knowledge and information, which determine the development of innovation, scientific and technological progress and the new state of human capital.

P. Romer's ideas were developed by World Bank experts D. Chen and H. Ki in the theory of knowledge and endogenous growth [2]. Using a two-sector model of a closed economy (including the manufacturing sector and the research and development sector), based on the application of the CobbDouglas function, which reflects the dependence of changes in productivity on certain factors, the authors link economic growth with increasing accumulation of financial resources in human capital development.

The issue of using financial resources to increase the level of human capital as a basis for economic growth of the territory is widely considered in recent decades and is the subject of numerous scientific discussions. According to conclusions of the World Bank, "empowerment results in the ability of the poor to influence government institutions that determine their living conditions by strengthening their participation in political processes and decision-making at the local level. And that means removing barriers - political, legal and socio-cultural - and increasing the assets of the poor so that they can effectively enter the markets" [3].

Thus, the hypothesis of the impact of the level of human capital development on the economic growth of the territory was developed by R. Birochy and M. Pozhebon in their proposed concept of critical financial education in the context of improving the financial inclusion of the entities of the community economy as one of its economic growth factors [4]. The empirical study was conducted by a municipality in Brazil, where providing community residents with access to information and communication technologies has resulted in significant socio-economic changes. After collecting data through surveys and using the method of coding economic information, scientists have concluded that financial education is the driving force of financial inclusion of low-income entrepreneurs and ensuring their access to financial resources.

Theoretical and methodological development of the issues raised by foreign and domestic scientists is carried out mainly at the regional, national and international levels. Despite significant 
developments, the theoretical aspects of the development of territorial communities, the definition of the basic principles and factors of their sustainable progress in conditions of uncertainty have not been properly presented, and therefore require in-depth study.

\section{ReseARch ObJective, Methodology AND DATA}

The purpose of the article is to determine financial factors in the latest theories of economic growth of territorial communities. The object of research in this article are the latest theories and factors of economic growth and long-term development of territorial communities. The methodological basis of this study are the fundamental provisions and principles of the theory of endogenous growth, sustainable and inclusive development, a number of domestic and foreign empirical studies on this issue. A set of specific methods of scientific knowledge, namely: logical generalization, analysis, synthesis, scientific abstraction, historical approach provided the opportunity to realize the integrity of scientific research.

\section{RESUlTS AND DisCUSSION}

The decentralization reform has enabled territorial communities to become a full-fledged subject of territorial management by obtaining the appropriate powers and resource base, which provides for the responsibility of local governments for the socio-economic development of the territory.

The study of the theoretical foundations of the development of territorial communities necessitates the definition of the essence of this definition. Therefore, the generalization of scientific approaches to its understanding suggests that the territorial community should be understood as a naturally formed human community organized in a certain area, characterized by a set of permanent ties and common interests in their livelihood and socio-economic development. At the same time, emphasizing the role of the territorial community in the context of its administrative-territorial determination as a subject of administrative relations in the system of state formation, it should be considered as a primary subject of local self-government with self-formed governing bodies endowed with the rights and responsibilities to address issues of local significance, which is the representative of the local community in the political arena and the owner of communal property in the relevant territory.

This approach to the interpretation of the category "territorial community" allows you to systematize the set of its explicit features:

- territorial - a territorial community is formed on a certain territory;

- natural - territorial community is formed and developed on the basis of self-organization, social and economic activity of its members and the need for constant development, following the principle of self-regulation;

- socio-psychological - territorial community exists subject to self-identification of each member of the community as part of it and awareness of the commonality of their interests. The community is first and foremost a system of constant communicative connections between members of the community;

- historical and cultural - the community exists and develops over time, so when choosing the direction of its development it is necessary to take into account the historical aspects of community evolution, its cultural and customary features that significantly affect the psychological climate in the community and endogenous relationships;

- organizational and functional - territorial community is a system with horizontal organization of political and social networks, which operates based on democratic principles of development and subject to the participation of its members in solving their livelihood issues with the possibility of selfstructuring and creation of internal organizational structures;

- political - the territorial community is a subject of legal relations and a representative of the local community in the political arena;

- economic - the local community is the owner of communal property located on its territory, and its members are payers of tax payments to the local budget. The community operates to provide its 
members with quality public services, can be a participant in production processes and is a collective consumer.

This emphasizes the priority of considering the territorial community as an economic system that operates to achieve social welfare, political goals and economic growth, provided the effective use of available territorial and spatial resources in the context of ensuring the triad of interests of the local community, territory and individual members.

It should be noted that the problem of management and rational use of available resources and opportunities to ensure economic growth of territorial communities, which in domestic conditions is one of the key targets for the development of the territory, is at the stage of formation and search for optimal solutions. Despite the significant number of scientific approaches and theories aimed at solving local development issues, none of them provides a complete and systematic solution to the problems of local communities and does not take into account current trends and features of their development and condition. This requires understanding a new theoretical approach to the development of territorial communities based on the synthesis and combination of basic guidelines and principles of modern scientific concepts and models of local development.

Popular in recent decades and formed as an independent direction of the theory of economic growth is the model of endogenous growth, aimed at reducing inequality of economic development through the use of internal factors, mechanisms of management and governance. The development of the theory was ensured not only by scientific research and the work of economists, but also by representatives of geography and sociology, which resulted in the diversity of trends within the model (P. Romer's theory of endogenous scientific and technological progress, "schooling model" and "learning by doing"). Lucas, the concept of bottom development by K. Weaver, the decentralization development of B. Planck, the concept of growing development of M. Basand, the theory of rise of $\mathrm{W}$. Rostow, the theory of convergence of J. Lafontaine and P. Idalo, the theory of local development developed by F. Bouvet, Yu. Dion, P.-A. Tremblay, B. Pecur, etc.).

Analysis of numerous approaches and scientific concepts within the theory allows us to identify three key principles that underlie endogenous growth and are common to all areas, namely: 1) territoriality - territory is the basis for endogenous development, which is characterized as integrated because it is carried out in to a limited extent, and which has certain features of autarky; 2) interdependence - the achievement of endogenous growth is the result of the impact and efficiency of use of each element of the limited space within which it is provided (natural, cultural, social, economic, etc.); 3) democracy - endogenous growth is possible only under the conditions of existence and appropriate level of development of democratic institutions in a given area and is based on meeting the basic needs of the population (nutrition, education, health, work, etc.) through the use of local economic potential.

In the context of our study, it is advisable to turn to the analysis of local development concepts that stand out within the theory of economic growth. Given the rather wide range of concepts and models of local development, which relate to finding ways to develop industrial areas, innovation circles, the application of the principles of flexible specialization for economic development of administrativeterritorial formations, etc. [5], and differ primarily in emphasizing the superiority of one principle over others [6], define the common ideas on which they are based. Thus, the initial conditions of the process of endogenous economic growth at the local level are the production of innovation, the ability to adapt and the ability to regulate. B. Pecur emphasizes this, noting the key role of the dynamism of the actors in ensuring these conditions [7], as well as M. Bassan, I. Pedrazzini, F. Feinar and R. Peranjake, who note that local development can be interpreted as a partnership agreement on creating favorable conditions for the implementation of local initiatives in the context of community capacity building, adaptation to new conditions, search for new forms and mechanisms of development, which organizational and production methods will be aimed not only at economic benefits but also at solving social, cultural and environmental issues character [8].

Interesting in the context of ensuring economic growth at the local level is the model of rural development developed by DA McGranahan, T. Vojan and D. Lambert in the United States as a 
synthesis of the theory of endogenous growth and creative economy [9]. The authors of the model identify three main factors of economic growth in rural areas: entrepreneurship, creative class and recreational resources. The basis of the proposed model is the development of entrepreneurship and the involvement of representatives of the creative class through the formation and supply of life in rural areas. At the same time, scientists note that the application of the model is appropriate for the local economy in terms of declining employment in traditional industries and reducing production, which is characterized by the use of low-skilled labor.

Among domestic economists, the issue of endogenous growth has been studied by many scientists. At the same time, analyzing the theory of endogenous growth, we agree with the conclusions of J. Zhalil, who, studying the problem of endogenization of economic development, identified the main areas of economic growth, which are fully consistent with modern conditions of territorial communities in Ukraine:

- investment and innovation policy, in particular the financial tools of their implementation, which set the institutional mechanisms for investment of financial resources;

- business development in the context of increasing the capitalization of economic potential;

- development of human capital in order to increase its productivity increase networking (in particular, as proved by M. Vozhnyak, there is a clear positive relationship between the development of education in a given area and the level of economic growth, and investment in education and health have a positive impact on productivity of the community and activate its members to solve problems of socio-economic nature [10]);

- development of communication environment and development of network relationships;

- decentralization of processes of identification and involvement in economic circulation of available and potential resources of economic development [11].

Determining the directions of achieving economic growth of territorial communities requires taking into account the influence of external conditions, the variability of political and economic conditions and unforeseen factors, the number of which has increased significantly in the context of globalization. In this context, it is appropriate to focus on the study of World Bank experts [12], who emphasize the need to fully support the transformation of local economies during and after the Covid-19 pandemic for long-term economic recovery and sustainability. Ensuring the economic growth of territorial communities in rural areas, they propose to carry out in three directions: 1) search and development of strengths and strengths of a particular area; 2) attracting investment for the development of the local business environment; 3) development of basic infrastructure and provision of Internet access.

At the same time, due to an in-depth analysis of the economic development of local communities in different countries during the Covid crisis, the categories of the population most "affected" by the impact of measures to combat the pandemic were identified. Accordingly, the World Bank recommends that local governments focus on supporting women, youth, the informal sector, and micro and small enterprises on a more sustainable basis. That is, the World Bank emphasizes the need to achieve economic growth while ensuring social justice, which meets the need to implement the Global Sustainable Development Goals for 2015-2030.

The issue of inclusive development is widely represented in the research of foreign scholars, but conceptually and theoretically it has not been developed. According to the UN, inclusiveness is based on the involvement of all marginalized and excluded groups in the development process as stakeholders [13]. The main principles on which the theory is based are: participation - maximum involvement of all community members in the process of its development; accessibility and nondiscrimination - ensuring equal access to opportunities for all members of the community.

The issue of inclusive development is widely represented in the research of foreign scholars, but conceptually and theoretically it has not been developed. According to the UN, inclusiveness is based on the involvement of all marginalized and excluded groups in the development process as stakeholders [13]. The main principles on which the theory is based are: participation - maximum involvement of all community members in the process of its development; accessibility and nondiscrimination - ensuring equal access to opportunities for all members of the community. 
It is worth noting that the progress of the theory of inclusive development took place in the context of the development of the state, international relations and the individual. And only in recent years has the theoretical foundations of inclusiveness been directed to the problems of local development. To date, the most complete, in our opinion, definition of inclusive local development has been given by J. Gupta, N. Pove and M. Ross-Tonen: it is a new dimension of development that focuses on the poorest and most marginal members of society, taking into account economic, social and environmental aspects and structural factors that prevent the poorest participants from participating in the development process [14]. In this context, scholars also identify the components of inclusive development at the level of territorial communities: providing equal opportunities for development and equitable distribution of benefits; providing economic opportunities for community members; public participation; environmental protection; adaptive capacity, which provides mitigation of the shocks of existence for different groups within the community [15].

Thus, the inclusion of members of the territorial community in the context of economic growth involves the most effective use of human capital in the direction of enhancing social, labor, managerial and economic relations and the formation of the business environment. At the same time, it is also designed to provide quality living space for all residents of the community. Therefore, we can distinguish two vectors of achieving inclusive development of territorial communities: internal - the maximum involvement of community members in the process of its development; external - ensuring access of members of the territorial community to the opportunities provided by more developed communities.

A component of the theory of inclusive development is the concept of financial inclusion, which substantiates the problem of "banking deserts" - territorial communities whose members do not have access to financial services [16]. Historically, the category of territorial communities - "banking deserts" include poor communities, and lack of access to financial services, despite the factors of slowing economic development, is an additional factor hindering economic growth and, consequently, discrimination against the community $[17,18]$.

An interesting aspect, which was substantiated in the scientific research of researchers, is to identify the reasons for the inefficiency of the branches of powerful banks in the so-called "banking deserts". As M. Baradan notes, banks "do not speak the financial language of the poor", and therefore do not understand that poor consumers "can not be offered banking services as if they were just rich people with less money" [6]. Applying the scientific findings of the psychology of poverty to the theory of financial inclusion reveals differences in the behavior and prerogatives of people in underdeveloped (poorer) communities: poor consumers tend to be more community-oriented than wealthier; they are more concerned with the needs and well-being of their community [17, 19]. This leads to the choice of appropriate mechanisms for banking services to the population of such communities, including the development of utility banks, as consumers of banking services in poorer communities often exaggerate the importance of the utility bank for their community. Accordingly, researchers suggest that banking institutions that "enter" the "banking desert" attract consumers, emphasizing the link between the financial interaction of the consumer with the bank and the well-being of the community.

In general, the basis of the concept of financial inclusion is based on solving the following tasks: 1) determining the role of financial services in an inclusive economy and the development of microfinance models (rural savings and loan associations, self-help groups, credit unions) to ensure financial inclusion of the community; 2) research on the financial behavior of low-income groups to develop more appropriate financial products, especially savings, insurance, payment services, value chain financing and innovative community-based financing models; 3) search for opportunities and ways to establish links with private sector financial institutions, use of mobile banking, etc.; 4) development of approaches to the integration of community-based microfinance models in empowerment strategies for marginalized community members. The main advantages of financial inclusion include: at the level of individuals, financial inclusion results in increased savings, investment in education and resilience to financial shocks; at the community level - reducing financial inequality and economic growth in general [20]. 
To form a comprehensive approach to economic growth at the level of local communities, in addition to taking into account the principles of endogenous growth and inclusive development, it is necessary to focus on the guidelines of sustainable development, in particular the scientific concept of Nobel Laureate E. Ostrom on rational use of shared resources.

By definition, shared resources are a "natural or artificial resource system" [21], which has the following characteristics: exclusivity (access to a shared resource can be limited at minimal cost), rivalry (competition for access to a shared resource), divisibility (the ability of a resource to be divided into shares) and exhaustiveness. Having conducted numerous empirical studies, E. Ostrom came to a significant conclusion: the management of shared resources by the community that uses them can be characterized by much higher efficiency than when transferring them to private ownership or through public administration; at the same time, methods of managing such resources should differ taking into account territorial, economic, customary differences. Therefore, on the basis of the conducted researches, the author has formed eight principles of effective management of common resources:

1) defining clear boundaries of the common resource;

2) formation of clear rules and norms for the use of common resources based on the needs of the community and the conditions of its development;

3) democratization of the joint resource management process;

4) control over the use of shared resources;

5) formation of a mechanism of graduated sanctions against violators of the rules of using a common resource;

6) formation of a mechanism for effective and rapid resolution of conflicts between users of the resource;

7) formation of an effective effective system of joint resource management, starting from the local level to the regional or state [22].

In the context of defining the concept of "common resources" by E. Ostrom and on the basis of elaboration and supplementation of the classification of common resources of rural communities, carried out by a team of authors led by V. Nelepa [23], we distinguish the main groups of common resources, information and resources of the socio-economic sphere (Fig. 1).

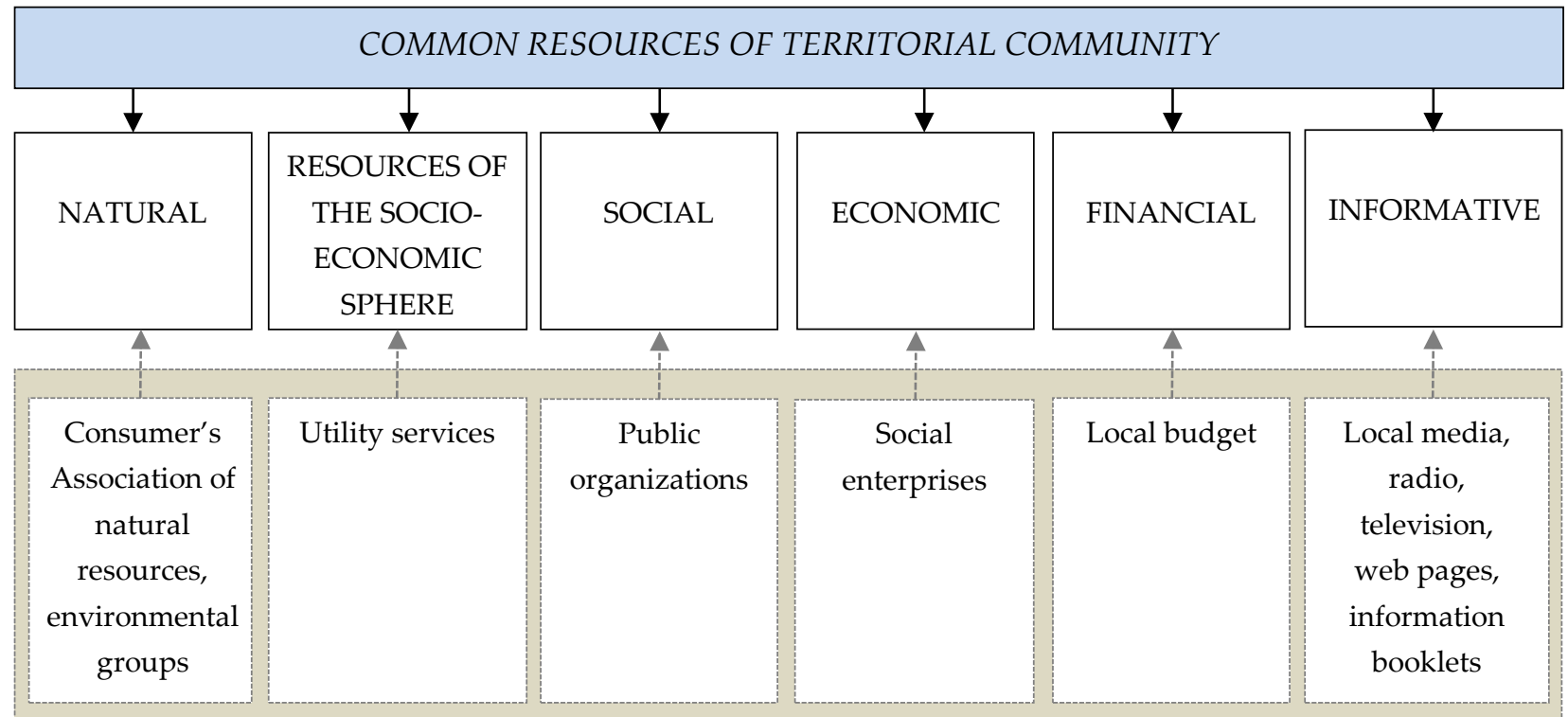

ORGANIZATIONAL MANAGEMENT METHODS OF COMMUNITY COMMON RESOURCES

Fig. 1. Types of common resources of territorial community and organizationalmethods of their management. Source: compiled by the authors. 
Thereby, the definition in the analysis of scientific theories and concepts of directions and principles of development of territorial communities allows to systematize the factors of their economic growth, which can be conditionally grouped into five groups: natural (including natural resources of the territory); human development factors (including demographic and behavioral (knowledge, skills, motivation, reactions) characteristics of community members); social (taking into account the institutions that promote the development of human capital and determine the areas of management and development of the territory (family, community, enterprises, public organizations, volunteer organizations)); productive (material goods and fixed assets that contribute to the production process); financial.

In this study, the main attention is paid to the group of financial factors of economic growth of territorial communities, and therefore in the process of identifying guidelines for the development of territorial communities in the analysis of economic growth theories, the main attention should be paid to substantiating such factors (Fig. 2).

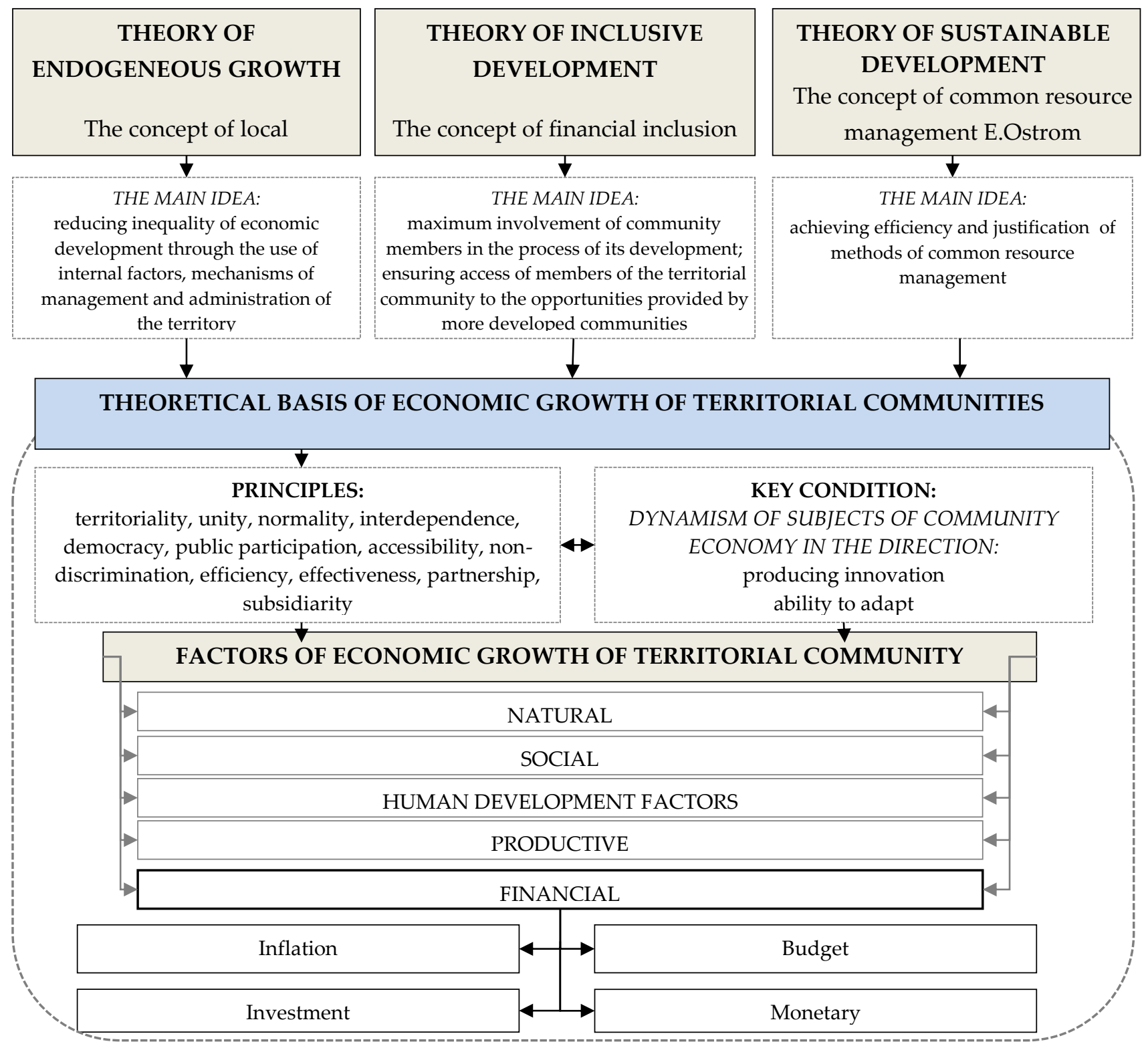

Fig. 2. Selection of financial factors of development of territorial communities in the context of theories of economic growth. Source: compiled by the authors. 
The financial factors of economic growth of territorial communities include:

- budget - includes features of formation and use of the local budget;

- investment - involves taking into account the investment policy of the self-government body and identifying the features of the investment direction of the financial resource in community development;

- inflation - a factor influencing changes in the general level of prices and purchasing power of money on the economic development of the territorial community and economic entities in its territory;

- monetary - a factor that allows you to assess access to financial resources, as well as the turnover, distribution and redistribution of money capital between economic entities.

\section{CONCLUSiOnS}

The selection of financial factors of economic growth of territorial communities in the context of the synthesis of the theory of endogenous growth, the theory of inclusive development and the theory of sustainable development contributes to a comprehensive approach to determining the ways of development of territorial communities. After all, the study of financial factors of territorial communities in the context of the analyzed theories will be carried out from different angles: in the theory of endogenous growth - from the standpoint of stimulating economic development and overcoming economic and social inequality, in the theory of inclusive development - from the standpoint of community involvement, which are in the risk group, in the concept of joint resource management the finances of the territorial community are considered as one of the common resources of the community, which requires finding an effective approach to its management.

\section{Acknowledgements}

The study was conducted under the grant 2020.02 / 0215 "Financial determinants of ensuring regions and territorial communities' economic growth based on behavioural economy" with the support of National Research Foundation of Ukraine.

\section{REFERENCES}

[1] Venger V.V. Evolution of views on the theory of economic growth. Economy and Society, 2 (2016), 3-9. (in Ukrainian)

[2] Chen Derek H.C., Kee H.L. A Model on Knowledge and Endogenous Growth. World Bank Policy Research Working Paper, 20433 (2004). The World Bank, Washington D.C. Available at: https://openknowledge.worldbank.org/handle/10986/8878

[3] World development report 2000/2001: Attacking poverty. World Bank, Oxford University Press, New York, USA, 2000. Available at: https://openknowledge.worldbank.org/handle/10986/11856

[4] Birochi R., Pozzebon M. Improving financial inclusion: towards a critical financial education. Framework. Rev. adm. empres, 56 (3) (2016). doi: 10.1590/S0034-759020160302

[5] Ryeznikova N.V., Ivashchenko O.A. The problem of economic development and growth in the context of overcoming global asymmetries. Odesa National University herald, 21 (1) (2016), 55-59. Available at: http://nbuv.gov.ua/UJRN/Vonu_econ_2016_21_1_14 (in Ukrainian)

[6] Bouvet F. Recherche sur les fondements méthodologiques des politiques économiques environnementales confrontées à la notion de développement soutenable. Université Panthéon-Sorbonne, Paris, 2001. (in French)

[7] Pecqueur B. Le developpement local: mode ou modele? In: Alternatives économiques. Série Poche. Syros/Alternatives, Paris, 1989. (in French) 
[8] Bassand M., Hainard F., Pedrazzini Y., Perrinjaquet R. Innovation et changement social: actions culturelles pour un développement local. Presses Polytechniques Romandes, Lausanne, 1986. (in French)

[9] McGranahan D., Wojan T., Lambert D. The rural growth trifecta: outdoor amenities, creative class and entrepreneurial context. Journal of Economic Geography, 11 (3) (2011), 529-557.

[10] Vozhnyak M.H. New approaches to the analysis of the mutual influence of social inequality, human capital and economic growth. International economic policy, 1-2 (16-17) (2012), 35-54. Available at: http://nbuv.gov.ua/UJRN/Mep_2012_1-2_4 (in Ukrainian)

[11] Zhalilo Ya. A. On the institutional basis of endogenization of economic development. Paradigmatic shifts in the economic theory of the XXI century: materials of the III International scientific-practical conference. Kyiv, November 2-3, 2017. KNEU, 2017, 763. (in Ukrainian)

[12] Sharma S. World Bank says 'local economic development' is need of hour; lists out these 3 focus areas. Financial Express, (2020). Available at: https://www.financialexpress.com/economy/world-bank-sayslocal-economic-development-is-need-of-hour-lists-out-these-3-focus-areas-rural-livelihoodrecovery/2090879/

[13] Disability and Development. Inclusive development. Handicap international. AFC. Available at: http://www.hiproweb.org/fileadmin/cdroms/Handicap_Developpement/www/en_page61.html

[14] Gupta J., Pouw N., Ros-Tonen M. Towards an Elaborated Theory of Inclusive Development. European Journal of Development Research, 27 (4) (2015), 541-559. doi: 10.1057/ejdr.2015.30

[15] Bos K., Gupta J. Inclusive development, oil extraction and climate change: a multilevel analysis of Kenya. International Journal of Sustainable Development \& World Ecology, 23 (6) (2016), 482-492. doi: 10.1080/13504509.2016.1162217

[16] Mende M., Salisbury L.C., Nenkov G., Scott M. Improving Financial Inclusion through Communal Financial Orientation: How Financial Service Providers Can Better Engage Consumers in Banking Deserts. Journal of Consumer Psychology, 30 (2) (2020), 379-391.doi: 10.1002/jcpy.1103

[17] Baradaran M. How the poor got cut out of banking. Emory Law Journal, 62 (3) (2013), 483-548. Available at: https://scholarlycommons.law.emory.edu/elj/vol62/iss3/1

[18] Morgan D., Pinkovskiy M., Yang B. Banking deserts, branch closings, and soft information. Liberty Street Economics. Federal Reserve Bank of New York, 2016 Available at: https://libertystreeteconomics.newyorkfed.org/2016/03/banking-deserts-branch-closings-and-softinformation.html

[19] Piff P.K., Stancato D.M., Martinez A.G., Kraus M.W., Keltner D. Class, chaos, and the construction of community. Journal of Personality and Social Psychology, 103 (6) (2012), 949-962. doi: 10.1037/a0029673

[20] Demirguc-Kunt A., Klapper L., Singer D., Ansar S., Hess J. Global Findex Database 2017: Measuring financial inclusion and the fintech revolution. DC: World Bank, Washington, 2018. doi: 10.1596/978-1-4648$1259-0$

[21] Ostrom E. Joint management. Evolution of institutions of collective action. Nash chas, Kyiv, 2012. (in Ukrainian)

[22] Liberto D. Elinor Ostrom. Investopedia. Available at: https://www.investopedia.com/terms/e/elinorostrom.asp

[23] Nelep V., Fursenko M., Vysots'ka O., Fursenko I. Management of common resources in rural areas: in the field of Nobel Laureate' research. Ekonomika APK, 10 (2014) 92-98. Available at: http://eapk.org.ua/en/contents/2014/10/92 (in Ukrainian)

Address: Halyna Voznyak, Krystyna Patytska, Taras Kloba, SI “Institute of Regional Research named after M. I. Dolishniy of the NAS of Ukraine", 4 Kozelnytska St., Lviv, 79026 Ukraine.

E-mail: gvoznyak@gmail.com, pelechata@meta.ua, taras.kloba@gmail.com

Received: September 25, 2020; revised: November 15, 2020. 
Возняк Галина, Патицька Христина, Кльоба Тарас. Детермінація фінансових чинників у новітніх теоріях економічного зростання територіальних громад. Журнал Прикарпатського університету імені Василя Стефаника, 7 (3) (2020), 49-59.

В сучасних умовах забезпечення економічного зростання територіальних громад потребуе теоретичного переосмислення та додаткового дослідження, позаяк нові викдики негативно позначились на добробуті населення та подальшому поступі.

Метою статті є детермінація фінансових чинників у новітніх теоріях економічного зростання територіальних громад.

Узагальнено наукові підходи до визначення поняття “територіальна громада" запропоновано власний підхід та обгрунтовано основні ознаки територіальної громади (територіальна, природна, соціально-психологічна, історично-культурна, організаційно-функціональна, політична, економічна). Акцентовано на потребі нового теоретичного підходу до розвитку територіальних громад на основі синтезу і поєднання засадничих орієнтирів і принципів сучасних наукових концепцій і моделей, їх трактування в контексті місцевого розвитку. Досліджено новітні теорії економічного зростання, серед яких: теорія ендогенного зростання, інкдюзивного розвитку та теорія стадого розвитку (виділено концепцію Е. Остром про управління спільними ресурсами громади). Обгрунтовано, що модель ендогенного зростання орієнтована на скорочення нерівності економічного розвитку через використання внутрішніх чинників, механізмів господарювання і управдіння територією. Виділено два вектори досягнення інклюзивного розвитку територіальних громад: внутрішній - максимальне залучення членів громади до процесу іiі розвитку; зовнішній - забезпечення доступу членів територіальної громади до можливостей, якими забезпечені більш розвинені громади. Акцентовано, що ключовою думкою у дослідженнях Е. Остром є досягнення ефективності та обгрунтування способів управління громадою спільними ресурсами. В межах теорії інклюзивного розвитку проведено огляд концепції фінансової інкдюзії, якою порушується проблема розвитку громад “банківських пустель". Вказано на існуванні взаємозалежності сприйняття членами територіальних громад - “банківських пустель” мождивостей та перспектив отримання банківських послуг, що вимагає залучення теоретичних основ поведінкової економіки до вивчення цього питання. Систематизовано чинники економічного зростання територіальних громад, які об'єднано у п'ять груп: природні, чинники людського розвитку; соціальні, виробничі та фінансові. До фінансових чинників економічного зростання територіальних громад віднесено: бюджетний; інвестиційний; інфляційний; грошово-кредитний. Обгрунтовано доцільність застосування ідей новітніх теорій економічного зростання у процесі аналізу фінансових факторів.

Ключові слова: територіальна громада, фінансові чинники економічного зростання, ендогенне зростання, інкдюзивний розвиток, сталий розвиток, спільні ресурси, фінансова інкдюзія. 